\author{
Yaroslava Belmaz \\ ORCID ID: 0000-0002-8823-640X \\ Doctor of Pedagogic Sciences, Full Professor \\ Head of the Department of Foreign Philology \\ Municipal Establishment \\ «Kharkiv Humanitarian Pedagogical Academy» of \\ Kharkiv Regional Council \\ Kharkiv, Ukraine \\ yaroslava_belmaz@ukr.net
}

\title{
CRITERIA OF EFFICIENCY OF HIGHER EDUCATION TEACHERS (US AND GREAT BRITAIN EXPERIENCE)
}

The article deals with the work efficiency issue of a higher education teacher. The author analyzes the main criteria for determining the efficiency of a higher education teacher in the US and Great Britain. It is established that a significant amount of research on the effectiveness of teachers' work is associated with a study of the validity of determining the rating of teachers among students. It was determined that the student rating of teachers is highly correlated with the personal qualities of the teacher, student achievement, student rating and assessment of teachers by the same students after a few years. The author emphasizes that it is impossible to evaluate teaching objectively, based on one source of information. American scientists identify the so-called triad of sources for the effective evaluation of higher education teachers: students, colleagues, and self-evaluation.

Key words: higher education teacher, efficiency of the work, criteria, source of evaluation, higher education teacher rating, the USA, Great Britain.

Introduction. Recently, scientists and educators from many countries around the world, including the United States and Great Britain, have been exploring the challenge of raising the efficiency of higher education. New social needs, economic ties and technologies have led to significant changes in higher education. However, despite the emergence of new technologies, the main academic source at the university remains the teaching staff. The students' knowledge and skills depend on these people to a large extent. Therefore, the problem of determining the effectiveness of the higher education teacher remains relevant.

Many American and British educators and psychologists (S. Young, D. Show, 1999;

K. Feldman, 1988; H. Marsh, 1987; P. Cohen, 2004; A. Greenwald, J. Gilmore, 1997 and others) have researched the issue of the definition of an effective higher education teacher profile. The main questions were and are the following: What is "effective teaching»? What term can define it? How can you measure the effectiveness of a higher education teacher?

The answers to these questions depend on many things, including such characteristics as the kind of an academic discipline, the size of the academic group, the ability of students, etc. Many works on the effectiveness of higher education teachers' activity are connected with the study of the validity of the ranking of teachers among students (L. Cohen, 2004; K. A. Feldman, 1986; K. J. Feldman, 1988; H.W. Marsh, 1987; S. Young, 1999). It was determined that the student's rating of higher education teachers is highly correlated with the personal traits of the teacher (K. J. Feldman, 1988; R. D. Renaud, 1996). For example, H. Marsh's research (1987) shows that students characterize charismatic and expressive teachers as highly effective, often not taking into account the content of lectures. P. Cohen (2004), A. Greenwald, J. Gilmore (1997), H. Marsh (1987) proved that the rating of teachers and courses is correlated with the achievements of students. H. Marsh (1987) outlined the following possible reasons for the high ranking of courses: a) effective teaching, which leads to more thorough training; b) satisfaction of students with high estimates, which gives rise to a desire.

A. Greenwald and J. Gilmore (1997) investigated the relationship between the student ratings of teachers and the grades obtained from one or another of the disciplines taught by the 
teacher. It was concluded that the loyalty of teachers leads to a more positive evaluation by his or her students. Researchers of this problem also tried to correlate the student rating with the rating of colleagues, administration, teacher selfesteem, and even with the performance of former students. A high level of positive correlation was found between student ratings and teacher ratings by the same students in a few years, indicating the stability of the assessment even after some time (L. Cohen, 2004; H. W. Marsh, 1987).

Although there is no universal faculty recognition system, each country, as well as each university, develops its own system and criteria for assessing the activities of higher education teachers. The United States and Great Britain have also gained some experience on this issue, which may also be useful for Ukrainian education.

The purpose of the article is to analyze the scientific research of American and British educators and psychologists on the problem of determining the effectiveness of the higher education teacher and to outline the range of the most important features and qualities of an effective higher education teacher.

Methods. To determine the basic theoretical positions of the study, to analyze the identification of the criteria of efficiency of higher education teachers in the United States and Great Britain, the following methods of research, such as analysis, synthesis, induction, deduction, comparison, systematization, were used.

Presenting main material. As S. Young and D. Shaw (1999, p. 671) point out, it is sometimes difficult to determine which features should be included in the list of rating assessments of the teacher's effectiveness, which of them are necessary, and which are simply desirable for effective teaching.

For example, K. Feldman (1986) suggests that when determining effective teaching, a factor such as knowledge of a subject may seem very important to students, although it may not actually differ in both good and bad teachers. A large number of sources on this issue confirms that the content of the evaluation should be multidimensional. $\mathrm{H}$. Marsh (1987) describes 9 Student 's Evaluations of Educational Quality (SEEQ): Learning as Value, Enthusiasm, Organization, Latitude, Group Interaction,
Individual Communication, Evaluation, Task, Workload Severity (H. W. Marsh, 1987).

K. Feldman (1986) concluded that stimulating interest and clarity in the presentation of the material are two of the most important dimensions for effective teaching. He also found that more effective teachers are knowledgeable in their subject, well organize classes, and show enthusiasm. Other less important characteristics were related to the management of the academic group. And such features as friendliness, readiness to come to the aid, openness to the thoughts of others were determined by the students important, but not so much as the above-mentioned.

Susan Young and Dale Shaw (1999, p. 674-676) have allocated 25 points for an effective teacher assessment:

1) the teacher is aware of his / her subject;

2) the teacher communicates effectively;

3 ) the teacher is enthusiastic about his / her activities;

4) the teacher is well prepared for each lesson;

5) the teacher creates a comfortable learning atmosphere;

6) the teacher adapts to the needs of students;

7) the teacher is tolerant of the ideas and views of others; students;

8) the teacher sincerely respects the

9) the teacher is a friendly person;

10) the teacher has a sense of humor;

11) the teacher encourages students to strive for the best results;

12) the teacher is a self-confident person; in teaching;

13) the teacher sincerely takes pleasure

14) the teacher is worried about student learning;

15) the teacher is able to explain the learning material clearly;

16) the teacher comments on important ideas;

17) the teacher uses good examples to explain concepts and ideas;

18) the teacher is achievable outside classes;

19) tasks are relevant in terms of volume and level; 
20) evaluation methods are appropriate;

21) the course on this discipline has increased my interest in the subject;

22) the course was well organized;

23) materials for the course (texts, tasks, etc.) were worthy and valuable;

24) the course has improved students' understanding of the concepts in the field;

25 ) the course was valuable to the student.

Lamont Flowers (2000) also studied the characteristics of an effective higher education teacher. He highlighted the so-called «Four $\mathrm{C}$ of an Effective College Teacher». Such a teacher should be concerned, committed, creative, and competent.

A concerned teacher wants to teach every student who is in his / her audience. He / she understands that the learning environment should be safe and in such a way that students can seriously analyze and design concepts and ideas. A teacher also believes that every student can show off his best traits and abilities, the positive consequence of which is that students, feeling the attitude of the teacher, seek to fulfill his I her expectations and take personal responsibility for the results of their studies. Finally, such a teacher acts on the so-called «zero-reject system», according to which each student is a value, regardless of the situation and circumstances.

Committed teachers are those who devote a lot of time to their work; they rarely complain of workload. They are committed to their activities, to each student, to the principles and ideas of democratic participation in the educational process.

The development of creative thoughts, broadening of the mind, promoting the discovery are the necessary conditions for teaching at universities, so creativity is an obligatory feature of the higher education teacher. The creative teacher is interested in presenting the learning material in an interesting and exciting way. $\mathrm{He} /$ she also tries to simulate a behavior that reflects creative thinking.

Undoubtedly, an effective teacher should be competent. He / she never ceases to study, constantly reads and conducts research; he / she is constantly improving his / her pedagogical skills. A competent teacher is obliged to explain to students how they can use the knowledge gained. Moreover, he / she demonstrates effective learning skills, for example through interactive or cooperative learning. He / she also participates in seminars, workshops, conferences, which allows us to explore new ways to solve old problems (L. Flowers, 2000).

Milton Hiddenbrand and Kenneth Feldman also identified the features of «a wonderful, incredible university teacher»:

1) stimulating style;

2) an ability of clear and understandable communication;

3) proficiency in the academic subject;

4) the teacher is trained and organized;

5) dynamic enthusiasm;

6) personal interest in students;

7) interactive skills;

8) flexibility, creativity, openness;

9) positive character;

10) devotion (M. Hiddenbran and others).

The researchers at the Center for Research on Learning and Teaching at the University of Michigan (Guidelines for evaluation teaching, 2019) identified some principles for

assessing the activity of a higher education teacher:

1. The multiplicity of methods, that is, the basic principle of evaluation of a teacher, in order to improve his / her activity, or for drawing up his I her characteristic, is the use of data from various sources.

2. Responsibility of the department, faculty, university. In order to be sure that the proposed evaluation system is acceptable and trustworthy, not only the administration but also the teaching staff should participate in its development. Due to the fact that different disciplines require different methods and evaluation criteria, the departments are responsible for their development. However, in order to ensure compatibility of standards within the university, the criteria and standards of assessment should be discussed at the departments and faculties and accepted as being taken into account when assigning posts and granting certain privileges.

3. Individual approach in the assessment of higher education teachers. An effective assessment of teaching should be individualized. Certainly, there are generalized evaluation systems, but in each particular case, it is necessary to take into account the specifics of 
the activity of a particular teacher, his / her experience, scientific interests, etc.

4. Wide spectral evaluation.

When evaluating teaching, then first of all it means work in the audience. But evaluation of teaching should cover a wide range of activities, such as:

1) development of educational curricula, new training courses, preparation of materials for the classes;

2) supervising the scientific work of students and postgraduates;

3) participation in examinations boards and councils for the defense of theses;

4) individual consultations for students;

5) supervising the student teaching;

6) work in laboratories;

7) mentoring of young colleagues;

8) participation in scientific experiments (Guidelines for evaluation teaching, 2019).

When evaluating the work of a higher education teacher, one should remember the need to refer to several sources, which are also drawn attention by American scientists dealing with this problem (R. M. Felder, R. Brent, 2004). They observe that it is impossible to evaluate impartially teaching activities based on a single source of information. Therefore, in determining the rating of teachers among students, you can really get useful information. For example, it is students who can disclose such aspects as clear explanation of educational material, teacher's attitude to students, the influence of a teacher on the desire to study a particular discipline, the ability to motivate students, etc. Studies confirm the validity of teachers' ratings among students (W. E. Cashin, 1995), which gives grounds for it to take into account when assessing the activities of the teaching staff. Although there is a perception that such ratings are not always objective. According to studies of American educators, the rating of teachers among students is highly correlated with the personal traits of a teacher.

As already mentioned earlier, $\mathrm{H}$. Marsh's research $(\mathrm{H}$. W. Marsh, 1987, p. 290) proved that students often appreciate those teachers who were distinguished by the charismatic and bright manner of conducting classes, without taking into account the content of lectures. The following possible reasons for the high ranking of courses were highlighted: a) effective teaching, which leads to more thorough learning; b) the satisfaction of students with high marks, which gives rise to the desire to «reward» the teacher, giving him / her a high rating.

In addition, there are issues in which students cannot be competent (compliance with the curriculum and syllabus, the optimality of and teaching methods and forms, the quality and effectiveness of assessment methods, etc.). These aspects can only be highlighted by colleagues. Moreover, as already mentioned, work in the audience is only part of the activity of the higher education teacher, and other activities can often be traced using the portfolio method.

Consequently, representatives of the University of Michigan and the University of North Carolina distinguish the so-called triad of sources of effective assessment of higher education teachers: students, colleagues and selfassessments (Guidelines for evaluation teaching, 2019).

Students as a source of evaluation.

1. Questionnaire on the effectiveness of teaching. Typically, after completion of the course, students fill out a specially designed form for evaluating the teacher's activity. Generally, they can assess teacher training, communication skills, ability to explain new material, ability to stimulate and interest students, attitudes towards students. Studies show that the evaluation of these criteria by students is sufficiently valid and reliable. Less professional students can judge the teacher's level of knowledge, scientific and compliance with the curriculum of the material, etc.

When developing questionnaires for students, it is advised to follow the following instructions:

- questions about the teacher and the educational course should be relevant;

- when evaluating the teacher in general, one must take into account polls not only of one year and one course, but several ones;

- since students do not always have specific terms when evaluating a teacher, more attention is paid to the general notion;

- it is necessary to take into account the specifics of the educational course;

- when solving personnel issues, the results of student surveys are taken into account only when most students participated in it; 
- questionnaires should have openended questions so that students have the opportunity to write their comments; it is useful for improving the teacher's teaching activities in the future;

- interpretation of the results should be carried out by experienced consultants who are able to provide constructive recommendations for improving pedagogical activity.

2. Information from former students. Former graduates, as well as current students, can evaluate teachers and educational courses. However, they have a certain advantage - the evaluation of a particular discipline through the prism of its effectiveness for their own career. Studies show that assessments of current and former students are highly correlated.

3. Interview of academic groups after the completion of the educational course.

4. Feedback with students during the course. This approach is useful for improving teaching activity in the process of work. Students are offered to fill in the forms of a progress evaluation of the effectiveness of teaching to obtain information on the state of affairs and, if necessary, adjust their activities.

5. Results of learning activity of students (C. M. Golde, 2001).

Colleagues

In most US universities, when assessing the effectiveness of teachers' activity, the views of colleagues are taken into account. It is suggested to conduct an evaluation on the following parameters:

1. Assessment of the work in the audience. Colleagues can get important information by observing a particular teacher's lesson. In particular, the following aspects are taken into account: the correspondence of materials and methods, the content and depth of the teaching material, the relationship of content with the syllable and the objectives of the course, the teaching method of a particular subject. The above-mentioned factors cannot be evaluated objectively by the students, namely, the colleagues are able to provide a competent assessment. When officially evaluating, it is important to have a standardized form in which the evaluation criteria are clearly defined. Moreover, today we are talking about preparing teachers for such activities as observing and evaluating colleagues. It is fairly believed that the assessment of the lesson will be more effective if the visitor acquaints himself with the course syllable, teaching materials, objectives of a particular class, etc.

2 Evaluation of the materials of the educational course. Colleagues can evaluate course materials such as syllabuses, textbooks, handouts, tasks, control and exam papers and materials, etc. Assessment of educational materials, in the first place, helps to improve them.

3. Evaluation of other activities (except teaching). Colleagues also benefit from the evaluation of various activities related to teaching, such as participation in syllable design, student research supervising, participation in events on higher education teaching improvement, research papers, etc. (Guidelines for evaluation teaching, 2019).

R. Brent and R. Felder (2004) add to this list also the results of student learning. They also emphasize that in assessing the activity of colleagues for the sake of objectivity, it is necessary to appoint at least two independent experts who would draw their conclusions according to standardized criteria.

Self-evaluation.

The main source of self-evaluation is the teaching portfolio. Teaching portfolio is a method that allows a teacher to gather and demonstrate information related to teaching activities, obtained from different sources for evaluation by others. Portfolio can serve for two main purposes: first, for solving personnel issues, and, secondly, for improving teaching activities. The staff of the Center for Research on Learning and Teaching at the University of Michigan (Guidelines for evaluation teaching, 2019) offer information to be combined into three areas:

1. Basic information about the teacher. This section can contain both general data and reflection on their own professional development, philosophy, goals and strategy of teaching, plans for the future, etc.

2. Surrounding. This section may include information about the faculty, the department in which the teacher works, his / her instructions (missions), the list of courses taught, the characteristics of the groups, the students with whom the teacher works.

3. Data on the teaching process: 
a) samples of teaching materials, for example, curricula, tasks for practical and laboratory studies, video recording of classes, etc.;

b) samples of student work, for example, exam papers, projects, etc.;

c) reflection on teaching and learning materials. For example, the teacher can comment on changes to the curriculum, innovative teaching methods, the specifics of assessing student knowledge, etc.

D. Pratt (1997) offers approaches to assessing teaching at a higher school to be divided into technical and content-related. Technical, in turn, are grouped in those focusing on responsibilities, and those that focus on techniques. The name of the approach to the assessment of teaching «a duty-based approach» was proposed by M. Scriven, understanding, under the notion of "duties", a fair attitude towards students, preparation and conduct of classes, assessment of student achievements (D. Pratt, 1997). This approach suggests that it is impossible to describe all possible variations of an "effective» teacher. The only source for assessing teaching activity, or rather a negative assessment, is the failure to fulfill its immediate responsibilities. The second technical approach to teaching assessment focuses on teaching techniques: planning classes, reading lectures, seminars, organizing discussions, receiving feedback from students.

In the content-based approach to assessing teaching the main criterion is content itself - without which it is impossible to teach. In assessing the activities of the higher education teacher, this approach distinguishes three aspects: planning, implementation and results.

Consequently, D. Pratt (1997) proposes to consider these aspects on the following indicators: beliefs.

\section{Planning: Assessing intentions and}

At this stage, it is necessary to evaluate five main points: educational material proficiency, material selection, material correspondence with the purpose and objectives, compliance with the requirements of the academic discipline, the relationship with other elements of the curriculum. The main sources for obtaining information on this aspect are standard documents - curriculum, syllable, assignments, test and exam materials, etc.

L. Schulman and P. Hutchings (1995) suggest a procedure for evaluating this aspect, which they call «reflexive notes». The essence of this procedure is that the teacher is offered to describe the plan of the class, or a separate fragment, trying to answer the following questions:

- What do students expect from this course? Why is it important?

- What are the main questions, arguments, concepts, authors, etc. to be considered?

- Whose works are key ones in this course? Why?

- Whose work will you not consider deliberately? Why?

- What are the most important tasks in this course?

- What are your criteria for evaluating your students?

- Did approach to teaching and evaluation criteria change over time? Why?

- In the process of getting results of tasks, answers to questions, etc., what would you like to improve in teaching this course?

- How is this course associated with other disciplines?

For full information, it is important to consider the lesson plan and "reflective notes» in a complex: the plan of the lesson and the system of tasks demonstrate examples of educational material, and "reflective notes» helps to understand the choice of this material.

Implementation: Assessing the relevance of actions, intentions and beliefs.

Evaluating the implementation of the plan, first of all the focus is on technical skills (objective attitude towards students, following the principles of science, accessibility, ability to organize a discussion, etc.). But without understanding what the teacher wanted to bring to his / her student the picture would be incomplete. When evaluating this aspect, the main source is the observation of colleagues for the activities of the teacher. It is important that the evaluation was not carried out on the results of a single observation of classes, and conclusions were drawn on the basis of the sessions of classes observation by several colleagues. American Association for Higher 
Education - AAHE drafted peer-review of teaching (Peer Review of Teaching Project), which provided several recommendations for successful peer-observation and peer-evaluation:

1) Avoid unexpected appearance in an audience and assess activity without a preliminary conversation with a teacher whose activity is evaluated;

2) In a meeting before observation of classes it is expedient to discuss the purpose, objectives, intentions of the colleague. After the class it is necessary to ask the colleague to make self-assessments;

3) It is advisable to conduct a series of visits throughout the course;

4) Use a group approach in which a couple or a small group of teachers observe one another's classes and analyze them;

5) Be open not only to teach, but also to learn in the process of attending and observing (D. Pratt, 1997).

Results: Assessing the academic course and higher education teachers by students.

Summarizing the study experience,

D. Pratt (1997) formulated seven principles for assessing the pedagogical activity of higher education teachers:

1. Evaluation should be tolerant, in the course of which respect for the diversity of actions, intentions and beliefs is traced.

2. Evaluation should be guided by a number of sources, not one, and these sources should earn trust.
3. Evaluation should cover both the technical and content-related aspects of teaching.

4. Evaluation should include planning, implementation and results.

5. Evaluation should relate to other forms of professional development of teachers.

6. Evaluation should improve the quality of teaching.

7. Evaluation should be carried out in the context of consultation with the persons responsible for providing information on individual teaching aspects.

Conclusions and perspects. The study shows that the problem of assessing the higher education teachers' activity often drew the attention of academics from many countries. It has been proven that there is no universal faculty recognition system in the United Kingdom and the United States, and each country, as well as each university, develops its own system and criteria for assessing the performance of higher education teachers.

As prospects for further research we consider investigation and development of evaluation criteria for Ukrainian higher education teachers, as well as a comparative analysis of the criteria for assessing the activity of higher education teachers in Ukraine and other countries, in particular, Great Britain and the USA.

\section{References}

Cashin, W. E. (1995). Student ratings of teaching: the research revisited. Kansas State University Center for Faculty Evaluation and Development. IDEA Paper, 32. September. Retrieved from www.idea.ksu.edu (eng).

Cohen, L. Manion, L., Morrison, K. (2004). Some tasks of the mentor. London: Routledge Falmer (eng).

Felder, R. M., \& Brent, R. (2004). How to evaluate teaching. Chemical Engineering Education, 38(3), pp. 200-202 (eng).

Feldmann, K. J. (1988). Effective college teaching from the students' and faculty's view: matched and mismatched priorities. Research in Higher Education, 28, pp. 291-344 (eng).

Feldman, K. A. (1986). The perceived instructional effectiveness of college teachers as related to evaluations they receive from students. Research in Higher Education. 18, pp. 3-124 (eng).

Flowers, L. (2000). The four C's of an effective college teacher: a commentary on exceptional college teaching. . Retrieved from http://www.tcrecord.org (eng).

Golde, C. M., \& Dore, T. M. (2001). At cross purposes: What the experiences of today's graduate students reveal about doctoral education. Philadelphia: The Pew Charitable Trust (eng).

Greenwald, A. G., \& Gillmore, G. M. (1997). Grading leniency is a removable contaminant of student rating. American Psychologist, 1997, 52, pp. 1209-1217 (eng).

Guidelines for evaluation teaching (2019). Retrieved from http://crlt.umich.edu/tstrategies/guidelines (eng). 
Hildenbrand, M., \& Feldman, K. (2011). Characteristics of the superior college teacher. Retrieved from http://www.ksu.edu/catt/edcip943 (eng).

Marsh, H. W. (1987). Students' evaluations of university teaching: Research findings, methodological issues, and directions for future research. Journal of Educational Research, 11, pp. 253-388 (eng).

Pratt, D. (1997). Reconceptualizing the evaluation of teaching in higher education. Higher Education, Vol. 34, pp. 23-44 (eng).

Renaud, R. D., \& Murray, H. G. (1996). Aging, personality and teaching effectiveness in academic psychologist. Research in Higher Education, 37, pp. 323-340 (eng).

Young, S., \& Show, D. (1999). Profiles of effective college and university teachers. Journal of Higher Education. V.70, 6, pp. 670-682 (eng).

\section{КРИТЕРИИ ЭФФЕКТИВНОСТИ ПРЕПОДАВАТЕЛЕЙ ВЫСШЕЙ ШКОЛЫ (ОПЫТ США И ВЕЛИКОБРИТАНИИ)}

Ярослава Бельмаз, доктор педагогических наук, профессор, заведующая кафедрой иностранной филологии Коммунального учреждения "Харьковская гуманитарнопедагогическая академия» Харьковского областного сонета, г. Харьков, Украина, e-mail: yaroslava_belmaz@ukr.net

Статья посвящена эфффективности работы преподавателя высшей школы. Автор анализирует основные критерии определения эфффективности преподавателя высшей школы в США и Великобритании. Установлено, что значительное количество научных исследований по эфрфективности работы преподавателей связано с исследованием валидности определения рейтинга преподавателей среди студентов. Было определено, что студенческий рейтинг преподавателей высоко коррелирует с личными качествами учителя, достижениями студентов, студенческим рейтингом и оценкой преподавателей теми же студентами через несколько лет. Автор подчеркивает, что невозможно оценить объективно преподавательскую деятельность, основываясь на одном источнике информации. Американские ученые выделяют так называемую триаду источников эфрфективного оценивания преподавателей высшей школы: студенты, коллеги и самооценка.

Ключевые слова: преподаватель, эффрективность деятельности, критерии, источник оценивания, рейтинг преподавателя, США, Великобритания.

\section{КРИТЕРІЇ ЕФЕКТИВНОСТІ ВИКЛАДАЧА ВИЩОї ШКОЛИ (ДОСВІД США ТА ВЕЛИКОї БРИТАНІї)}

Ярослава Бельмаз, доктор педагогічних наук, професор, завідувач кафедри іноземної філології комунального закладу "Харківська гуманітарно-педагогічна академія» Харківської обласної ради, м. Харків, Україна, e-mail: yaroslava_belmaz@ukr.net

у статті розглядається питання ефективності діяльності викладача вищої школи. Зокрема, автор аналізує критерії виявлення ефективності викладачів вищої школи США та Великої Британії. Зазначається, що проблема оцінювання роботи викладачів часто привертала увагу науковиів багатьох країн. Установлено, що значна кількість наукових досліджень щодо ефективності роботи викладачів пов'язана з дослідженням валідності визначення рейтингу викладачів серед студентів. Було визначено, що студентський рейтинг викладачів високо корелюється з особистими рисами вчителя, досягненнями студентів, студентським рейтингом і оцінюванням викладачів тими самими студентами через кілька років. Велика кількість джерел із зазначеної проблематики підтверджує, що зміст оцінювання має бути багатомірним. Установлено, що американськими науковцями були визначені деякі принципи оцінювання діяльності викладача вищої школи, зокрема автором аналізуються такі принципи, як множинність методів, відповідальність кафедри, фракультету, університету, індивідуальний підхід у оцінюванні викладачів, широкоспекторне оцінювання. При оцінюванні діяльності викладача вищої школи британські й американські освітяни наполягають на необхідність посилання на декілька джерел. Неможливо оцінити об'єктивно викладацьку діяльність, грунтуючись на одному джерелі інформації. Американські вчені виділяють так звану тріаду джерел ефрективного оцінювання 
викладачів вищої школи: студенти, колеги та самооцінювання. Одним із інформативних джерел оцінювання викладача вищої школи вважається портфоліо. Портфоліо може слугувати для двох основних цілей: по-перше, для вирішення кадрових питань, i, по-друге, для вдосконалення викладацької діяльності. Автором представлено рекомендації щодо взаємооцінювання викладацької діяльності в університетах, запропоновані американськими та британськими педагогами.

Доведено, що у Великій Британії та США не існує універсальної системи визнання профресорсько-викладацького складу, кожна країна і навіть кожен університет розробляють свою власну систему та критерії оцінювання діяльності викладачів вищої школи.

3-поміж перспективних напрямів дослідження зазначеної наукової проблеми автор вбачає вивчення та розробку критеріїв оцінки викладачів вищої освіти України, а також порівняльний аналіз критеріїв оцінки діяльності викладачів вищої освіти в Україні та інших країнах, зокрема Великобританія і США.

Ключові слова: викладач, ефективність діяльності, критерії, джерела оцінювання, рейтинг викладача, США, Велика Британія.

Стаття надійшла до редакції / Received 12.06.2019.

Прийнята до друку / Accepted 9.09.2019. 